\title{
Parotocinclus arandai, a new species of hypoptopomatine catfish (Siluriformes: Loricariidae) from the upper rios Jucuruçu and Buranhém, States of Bahia and Minas Gerais, Brazil
}

\author{
Luisa Maria Sarmento-Soares ${ }^{1}$, Pablo Lehmann A. ${ }^{2}$ \\ and Ronaldo Fernando Martins-Pinheiro ${ }^{1}$
}

Parotocinclus arandai, new species of the hypoptopomatine catfish, is described from small creeks in the upper rios Jucuruçu and Buranhém basins, at the border of Brazilian States of Bahia and Minas Gerais. Parotocinclus arandai is distinguished from all congeners from the Atlantic coastal basins of southeastern and eastern Brazil, except Parotocinclus bahiensis, by having the branched rays and interradial membranes of the pectoral and pelvic fins unpigmented in ventral view. The new species is distinguished from most Parotocinclus species, by having a small eye, 14.8-19.3 mm HL (except P. maculicauda and $P$. planicauda) and by the presence of a tuft of hypertrophied odontodes on the supraoccipital (except $P$. cristatus and $P$. cesarpintoi). Parotocinclus arandai is further distinguished by having an abdomen extensively naked, with a mosaic of few rounded platelets of irregular size and distributed over the pre-anal region (except P. bahiensis, P. minutus, P. spilosoma, $P$. cearensis, P. cesarpintoi and P. prata). A detailed comparison with congeners on eastern Brazil hydrographical region is provided, and information on the species habitat is given.

Parotocinclus arandai, espécie nova de cascudo hypoptopomatíneo, é descrita de pequenos riachos do curso superior das bacias dos rios Jucuruçu e Buranhém, na divisa estadual de Minas Gerais com a Bahia. Parotocinclus arandai é distinguida de todos os congêneres nas bacias costeiras do Atlântico do sudeste e leste do Brasil, exceto Parotocinclus bahiensis, por apresentar os raios ramificados e as membranas interradiais das nadadeiras peitoral e pélvica despigmentadas em vista ventral. A nova espécie é distinguida da maioria das espécies de Parotocinclus, por apresentar olho pequeno, 14.8-19.3 mm HL (exceto $P$. maculicauda e $P$. planicauda) e pela presença de um tufo de odontódes hipertrofiados no supraoccipital (com exceção a $P$. cristatus e P. cesarpintoi). Parotocinclus arandai é ainda distinguida pelo abdômen com extensas áreas nuas, apresentando um mosaico de poucas plaquinhas arredondadas de tamanho irregular e distribuídas na região pré-anal (exceto em $P$. bahiensis, $P$. minutus, $P$. spilosoma, $P$. cearensis, $P$. cesarpintoi e $P$. prata). Uma comparação detalhada com os congêneres na região hidrográfica do Leste do Brasil é apresentada e, adicionalmente são fornecidas informações acerca dos ambientes em que foram encontrados os cascudinhos.

Key words: Neotropical, Systematics, Cascudinho, Freshwater, Hypoptopomatinae.

\section{Introduction}

The Hypoptopomatinae is a monophyletic subfamily within the Loricariidae comprised of 19 genera with more than 80 species of armored catfishes called Cascudinhos (Carvalho et al., 2008). The monophyly of the genus Parotocinclus Eigenmann \& Eigenmann has been controversial. Schaefer
(1991) recognized Parotocinclus as monophyletic, considering the following characters: a robust short crest for the adductor musculature, a large first dorsal-fin spinelet, and a lateral line interrupted, terminating in two or four plates preceding the last lateral plate. In the same paper, Parotocinclus was regarded as the sister group of Schizolecis, in a clade also including Otothyris plus

\footnotetext{
${ }^{1}$ Museu de Biologia Prof. Mello Leitão, Laboratório de Zoologia. Av. José Ruschi no 4, Centro 29650-000 Santa Teresa, ES, Brazil. biobahia@nossacasa.net; ronaldo@nossacasa.net

${ }^{2}$ Laboratório de Ictiologia, Pontifícia Universidade Católica do Rio Grande do Sul. Av. Ipiranga, 6681, Caixa Postal 1429, 90619-900 Porto Alegre, RS, Brazil. lehmanncatfish@gmail.com
} 
Pseudotothyris. In the phylogenetic study of Schaefer (1998) Parotocinclus occupies a more basal position within the tribe Otothyrini. According to a parsimony analysis of phylogenetic relationships, Parotocinclus was recognized as a polyphyletic assemblage (Gauger \& Buckup, 2005), with species suggested to be members of undescribed taxa. Lehmann (2006), in the most recent hypothesis of Hypotopomatinae relationships, based on 169 characters of osteology and external morphology and 114 terminal loricariid taxa, found no evidence to support the monophyly of the tribe Otothyrini, and recognized Parotocinclus as a highly paraphyletic assemblage of species.

Since Garavello's (1977) revision of the genus, eleven new Parotocinclus species have been described. Currently the genus is composed of 23 species (Table 1). However, a new phylogeny of the Loricariidae in progress (P. Lehmann A. \& R. E. Reis) provides more information to estimate the phylogenetic relationships, the biodiversity of Parotocinclus, and therefore to rediagnose the subfamily Hypoptopomatinae. The goal of the present paper is to describe a new species of Parotocinclus, and provide a comparison with congeners in the Atlantic coastal basins of eastern Brazil.

\section{Material and Methods}

Straight-line measurements were taken point to point under a stereomicroscope with a Mitutoyo digital caliper, and recorded to tenths of a millimeter. Measurements followed Boeseman (1968: fig. 5) and Britski \& Garavello (1984). Standard length is expressed in mm. All other measurements are expressed as percents of standard length, except subunits of the head, which are expressed as percents of head length.

Tooth counts were performed separately for left and right dentaries and premaxillae. Bilateral average counts were determined as the mean between the left and the right side for each specimen. Dermal plate counts are: lateral plate series number of dermal bones along the lateral line, counted from the posterior process of pterotic-supracleithrum to posterior hypural margin; lateral to dorsal-fin base plates - number of lateral dorsal dermal bones along the dorsal-fin base; plates between dorsal and adipose fins - number of dermal bones in dorsal series between the last dorsal-fin branched ray insertion and the origin of the adipose-fin spine; plates between adipose and caudal fins - number of dermal bones in the dorsal series between the adipose membrane and posterior hypural margin; plates lateral to anal-fin base - number of dermal bones in ventral series along the anal-fin base; plates between anal and caudal fins - number of dermal bones in ventral series between the last anal-fin branched ray insertion and posterior hypural margin; preadipose plates - number of azygous plates preceding the adipose-fin spine. Fin-ray counts included the number of unbranched and branched rays in pectoral, ventral and caudal fins. Osteological terminology followed Schaefer (1997) and was studied in cleared and stained specimens (c\&s), following the procedures of Taylor \& Van Dyke (1985). Institutional abbreviations followed Leviton et al. (1985), with the exception of MBML for Museu de Biologia Professor Mello Leitão, Santa Teresa, Espírito Santo, Brazil and UF for University of Florida, Gainesville, Florida, United States of America.

\section{Parotocinclus arandai, new species Fig. 1}

Holotype. MNRJ 28296, female (38.7 mm SL), Brazil, Minas Gerais: Palmópolis, córrego Bananeiras on road Geribá-Palmópolis

Table 1. Summary of the distribution of Parotocinclus species.

\begin{tabular}{lll}
\hline & Species & Distribution \\
\hline 1 & P. amazonensis Garavello, 1977 & rio Amazonas basin \\
2 & P. aripuanensis Garavello, 1988 & rio Aripuanã basin \\
3 & P. bahiensis (Miranda Ribeiro, 1918) & rio Itapecuru basin, northern Bahia State \\
4 & P. bidentatus Gauger \& Buckup, 2005 & rio Paraíba do Sul basin, Rio de Janeiro State \\
5 & P. britskii Boeseman, 1974 & rio Orinoco basin and Atlantic coastal drainages of the Guianas \\
6 & P. cearensis Garavello, 1977 & rio Choró, Ceará State \\
7 & P. cesarpintoi Garavello, 1977 & rio Paraíba basin, Alagoas State \\
8 & P. collinsae Schmidt \& Ferraris, 1985 & rio Essequibo basin \\
9 & P. cristatus Garavello, 1977 & rio Almada basin and coastal rivers near Ilhéus, southern Bahia State \\
10 & P. doceanus (Miranda Ribeiro, 1918) & rio Doce basin, Espírito Santo State \\
11 & P. eppleyi Schaefer \& Provenzano, 1993 & upper and middle rio Orinoco basin \\
12 & P. haroldoi Garavello, 1988 & rio Sanharó, Piauí State \\
13 & P. jimi Garavello, 1977 & rio de Contas basin, southern Bahia State \\
14 & P. jumbo Britski \& Garavello, 2002 & rio Paraíba do norte basin and coastal rivers in Alagoas, Ceará, Paraíba and Pernambuco States \\
15 & P. longirostris Garavello, 1988 & rio Amazonas basin \\
16 & P. maculicauda (Steindachner, 1877) & coastal rivers at Rio de Janeiro and Espírito Santo States \\
17 & P. minutus Garavello, 1977 & rio Vasa-Barris basin, northern Bahia State \\
18 & P. muriaensis Gauger \& Buckup, 2005 & rio Paraíba do Sul basin, Rio de Janeiro State \\
19 & P. planicauda Garavello \& Britski, 2003 & rio Doce basin, Espírito Santo State \\
20 & P. polyochrus Schaefer, 1988 & rio Negro drainage, Amazon basin \\
21 & P. prata Ribeiro, Melo \& Pereira, 2002 & upper rio São Francisco \\
22 & P. spilosoma (Fowler, 1941) & rio Paraíba do Norte basin, Paraíba State \\
23 & P. spilurus (Fowler, 1941) & rio Salgado, Ceará State \\
\hline
\end{tabular}




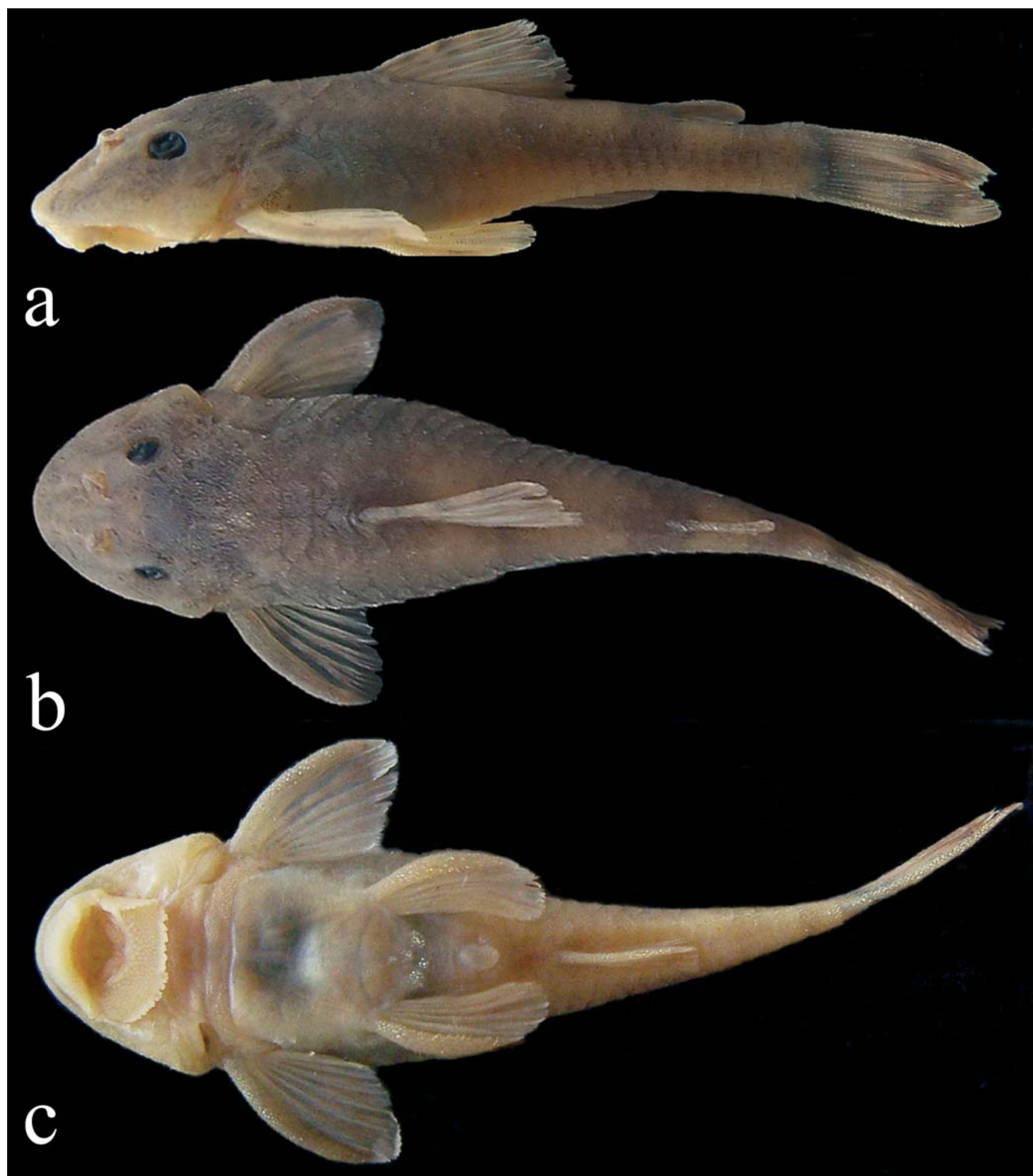

Fig. 1. Parotocinclus arandai, holotype, MNRJ 28296, female, 38.7 mm SL. Córrego Bananeiras on road from Geribá to Palmópolis, Minas Gerais, Brazil: (a) lateral; (b) dorsal; (c) ventral views.

(1644’48”S 40²5’46”W), 26 Oct 2004, L. M. Sarmento-Soares, A. T. Aranda, C. C. Chamon \& R. F. Martins-Pinheiro.

Paratypes. 239 specimens (16.6-42.8 mm SL). Brazil, Minas Gerais: MNRJ 28297 (23, 26.7-42.8 mm SL) collected with the holotype. MBML 1484 (6, 16.8-27.2 mm SL), MNRJ 32049 (6, 16.6-30.1 mm SL), córrego Sete Ranchos on road Cotajás - Santo Antônio do Jacinto, near border of Minas Gerais/Bahia (16³8'04”S 40¹7’52”W), 7 Jan 2007, L. M. Sarmento-Soares, A. T. Aranda, R. L. Teixeira \& R. F. Martins-Pinheiro. MNRJ 28295 (76, 2 c\&s, 16.6-38.6 mm SL), UF 18422 (4, 19.2-32.8 mm SL), ANSP 180644 (4, 19.2-32.8 mm SL), AMNH 235857 (4, 20.4-32.5 mm SL), AUM 
42002 (4, 22.5-34.6 mm SL), córrego da Onça, at border of Bahia (Jucuruçu) and Minas Gerais (Palmópolis) States (1649’49”S $40^{\circ} 15^{\prime} 05^{\prime}$ W), 26 Oct 2004, same collectors as holotype. Brazil, Bahia: MBML 1486 (12, 31.8-38.0 mm SL), MBML 2135 (3 c\&s, 26.5- 33.7 mm SL), MNRJ 32253 (87, 27.2-39.4 mm SL), MCP 43934 (3, 29.6-34.8 mm SL), and MCP 43935 (1 c\&s, 30.2 mm SL), córrego Sete Ranchos on road Cotajás-Santo Antônio do Jacinto, near border of Minas Gerais/Bahia (16³6’03”S 40¹7’04”W), 7 Jan 2007, L. M. Sarmento-Soares, A. T. Aranda, R. L. Teixeira \& R. F. Martins-Pinheiro. MBML 1492 (6, 28.2-34.4 mm SL), MNRJ 32039 (19, 26.9-39.0 mm SL), córrego Sete Ranchos on road CotajásSanto Antônio do Jacinto, near border of Minas Gerais/Bahia (16³6’03”S 40¹7’04”W), 7 Jan 2007, L. M. Sarmento-Soares, A. T. Aranda, R. L. Teixeira \& R. F. Martins-Pinheiro.

Diagnosis. Parotocinclus arandai is distinguished from all other Parotocinclus species of the Guyana Shield, Amazonas and Orinoco basin (except $P$. collinsae) by the absence of a triangular patch of dark pigmentation at the anterior dorsalfin base. The new species differs from the $P$. collinsae by the absence of the accessory teeth on the premaxilla and dentary. Parotocinclus arandai differs from all congeners of the Atlantic coastal basins of southeastern and eastern Brazil by having the branched rays and interradial membranes of the pectoral and pelvic fins unpigmented in ventral view; the rostral plate not exposed ventrally (except $P$. bahiensis, $P$. spilurus and $P$. prata). The new species is distinguished from most Parotocinclus species, except $P$. cristatus and $P$. cesarpintoi, by the presence of a tuft of hypertrophied odontodes on the supraoccipital; and by the extensively naked abdomen in adults, with a mosaic of few rounded platelets of irregular size and distributed over the pre-anal region (except $P$. bahiensis, $P$. minutus, $P$. spilosoma, $P$. cearensis, $P$. cesarpintoi, and P. prata).

Other features for recognition of the new species are as follows: The pectoral girdle exposed medial and laterally (Fig. 2a) (vs. only laterally exposed in $P$. spilosoma, $P$. cearensis, $P$. cesarpintoi, $P$. spilurus, $P$. jumbo, and $P$. prata); plates between anal and caudal fins 10 (vs. 9 in P. spilosoma, $P$. cearensis, $P$. cesarpintoi, $P$. haroldoi, $P$. spilurus, and $P$. jumbo; and 11 in $P$. maculicauda and $P$. doceanus); body deep, $16.1-18.6 \%$ SL (vs. less than $15 \%$ in P. cearensis, P.cesarpintoi, $P$. haroldoi and $P$. minutus); small orbital diameter, 14.8-19.3\% HL (vs. more than 20\% in Parotocinclus bahiensis, $P$. cesarpintoi, $P$. cearensis, $P$. cristatus, $P$. haroldoi, and $P$. jimi). Parotocinclus arandai differs from the $P$. jimi, $P$. planicauda, and $P$. jumbo by having all paired ribs associated with connective tissues of vertebrae, and from $P$. bahiensis by the abdominal lateral plates 2-4 (vs. 5-7 in $P$. bahiensis).

Description. Morphometric and meristic data presented in Table 2. Body moderately short, robust, head and anterior trunk elevated. Dorsal profile of head from snout tip to anterior orbital rim arched; straight between supracleitrum and dorsalfin origin; slightly concave from near adipose-fin base to caudal-fin base. Ventral profile from snout to pectoral-fin base concave, straight from pectoral-fin base to anus and then slightly concave to caudal-fin base. Snout rounded in dorsal profile, rostrum convex; trunk ovoid in cross section anteriorly, progressing to elliptical to triangular posteriorly. Cross-section of caudal peduncle compressed laterally. Eyes small (14.819.3\% HL) and superior. Dorsal fin when depressed reaching to vertical through origin of anal fin. Pectoral fin reaching to just beyond pelvic-fin origin; pelvic fin reaching beyond anus, ending just anterior to anal-fin origin.

Head and trunk usually without keels; odontodes evenly distributed and regularly arranged on head and body; small tuft of hypertrophied odontodes present, on posterior portion of supraoccipital. Premaxillary teeth 21-28; dentary teeth 2030. Oral disk ovoid; lower lip with prominent papillae, variable in size; upper lip about half depth of lower lip. Short maxillary barbel present (5.3-6.5\% SL). Infraorbitals five, two anteriormost larger than posterior ones. Infraorbital 3 in contact with prefrontal and second infraorbital, forming anterior corner of orbit. Infraorbital 4 with concave dorsal margin, forming ventral portion of orbital rim. Infraorbital 5 smallest, forming posterior orbital rim. Supraorbital crest conspicuous.

Posterior margin of supraoccipital followed by three plates on each side, medial pair sometimes fused together in one plate, followed by one pair and one azygous predorsal plate just anterior to dorsal-fin origin. Rostral margin with three postrostral bony plates between unpaired rostral plates on tip of snout. Rostral plate and subsequent postrostral plates around snout with slight ventral curvature. Dorsal rostral plate not exposed ventrally. First dorsal-fin spinelet small; spine of adipose fin prominent; adipose-fin origin vertically crossing at about end of adpressed anal-fin. Last anal-fin ray lacking posterior membrane. Abdomen with paired series of 2-4 small, median abdominal area naked, without platelets or with few rounded platelets of irregular size and distribution; region between pelvic fins with mosaic of few platelets, expanding over pre-anal shield region (Fig. 2). A median row of platelets only in large sized

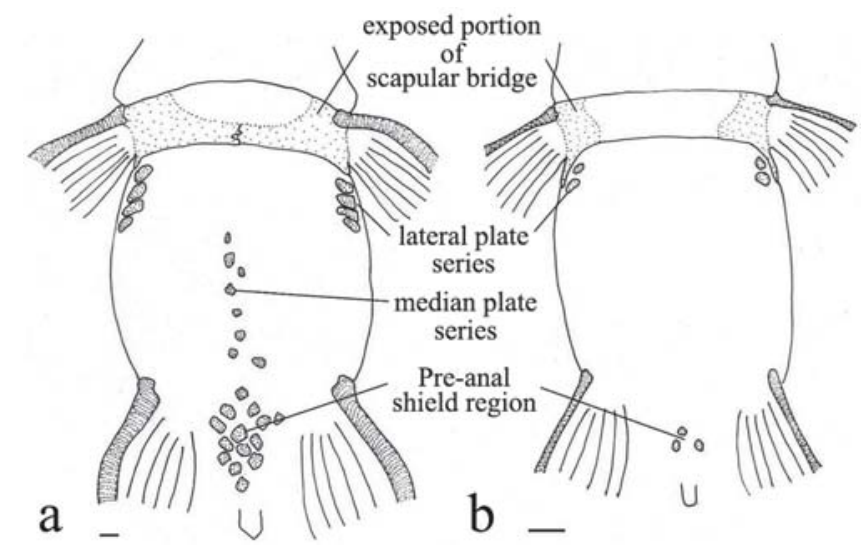

Fig. 2. Ventral view of abdominal region illustrating the lateral plates and preanal platelets in: (a) Parotocinclus arandai, MNRJ 28297 (37.1 mm) and (b) Parotocinclus bahiensis, MBML 2124 (29.6 mm). Scale bar $1=\mathrm{mm}$. 
specimens (larger than $24 \mathrm{~mm}$ SL). Young specimens (less than $24 \mathrm{~mm} \mathrm{SL}$ ) with platelets limited to pre-anal region. Lateral line incomplete with pores visible on first 5 or 6 anterior plates and sporadically along trunk between dorsal fin and caudal peduncle. Intermediate plates without pores 2-5.

Dorsal fin I,7; spinelet reduced in size, rounded or rectangular in shape. Nuchal plate present, trapezoid-shaped. Origin of dorsal fin at vertical behind pelvic-fin origin. Dorsal fin supported by 7 pterygiophores. Pectoral fin with one unbranched spine plus 6 branched rays. Pectoral-fin spine reaching pelvic-fin base when depressed. Pectoral girdle laterally and medially exposed; odontodes concentrated on lateral areas. Cleithrum largely exposed, coracoid covered by skin, exposed only near pectoral-fin spine attachment. Pectoral skeleton arrector fossae partially closed. Pelvic fin with one unbranched plus 5 branched rays. Pelvic fin margin rounded, not reaching anal-fin origin. Basipterygia sutured at midline, lacking fenestrae, ischiac process elongate. Anal fin with one unbranched plus 5 branched rays. Five anal-fin pterygiophores, each with one distal radial. First anal-fin

Table 2. Morphometric and meristic data for Parotocinclus arandai based on the holotype (MNRJ 28296) and 30 paratypes (AMNH 235857, ANSP 180644, AUM 42002, MNRJ 28295 and MNRJ 28297). Range includes holotype and paratypes $(\mathrm{n}=30)$.

\begin{tabular}{|c|c|c|c|c|}
\hline & $\begin{array}{c}\text { Holotype } \\
\text { MNRJ } \\
28269 \\
\end{array}$ & Range & Mean & SD \\
\hline Standard length & 38.7 & $32.4-42.8$ & 36.5 & 2.3 \\
\hline \multicolumn{5}{|c|}{ Percents of standard length } \\
\hline Body depth & 18.6 & $16.1-18.6$ & 16.9 & 0.7 \\
\hline Body width & 26.6 & $21.5-27.5$ & 25.3 & 1.4 \\
\hline Head length & 26.9 & $23.1-28.6$ & 25.7 & 1.3 \\
\hline Snout to dorsal-fin origin & 43.9 & $38.4-47.2$ & 42.8 & 1.9 \\
\hline Adipose-caudal distance & 21.4 & $21.0-28.5$ & 24.1 & 1.8 \\
\hline Anal-caudal distance & 28.9 & $24.7-36.1$ & 31.4 & 2.6 \\
\hline Caudal peduncle depth & 8.5 & 7.3 - 8.9 & 8.1 & 0.4 \\
\hline Pre-adipose distance & 77.8 & $72.2-81.2$ & 77.0 & 2.2 \\
\hline \multicolumn{5}{|c|}{ Percents of head length } \\
\hline Orbital diameter & 15.4 & $15.1-19.3$ & 17.3 & 1.2 \\
\hline Snout length & 63.5 & $63.3-69.1$ & 66.8 & 1.7 \\
\hline Interorbital width & 40.4 & $40.4-52.1$ & 44.5 & 2.8 \\
\hline \multicolumn{5}{|c|}{ Tooth Counts } \\
\hline Left dentary & 22 & $20-29$ & 23.4 & 2.3 \\
\hline Rigth dentary & 22 & $21-30$ & 24.7 & 2.3 \\
\hline Left premaxillary & 24 & $21-27$ & 23.7 & 1.9 \\
\hline Rigth premaxilary & 23 & $21-28$ & 23.8 & 1.9 \\
\hline \multicolumn{5}{|c|}{ Plate Counts } \\
\hline Trunk plate series & 24 & $24-25$ & 24.8 & 0.4 \\
\hline Plates lateral to dorsal-fin base & 4 & $4-5$ & 4.8 & 0.4 \\
\hline Plates between dorsal and adipose fins & 9 & $8-9$ & 8.9 & 0.3 \\
\hline Plates between adipose and caudal fins & 7 & $6-7$ & 6.9 & 0.3 \\
\hline Plates lateral to anal-fin base & 4 & $3-4$ & 3.6 & 0.5 \\
\hline Plates between anal and caudal fins & 12 & $11-12$ & 11.9 & 0.3 \\
\hline Preadipose plates & 1 & 1 & 1.0 & 0.0 \\
\hline \multicolumn{5}{|c|}{ Fin ray Counts } \\
\hline Total dorsal fin & $\mathrm{I}+7$ & $\mathrm{I}+7$ & & 0.2 \\
\hline Total pectoral fin & $\mathrm{I}+6$ & $\mathrm{I}+6$ & & 0.2 \\
\hline Total ventral fin & $i+5$ & $i+5$ & & 0.0 \\
\hline Total anal fin & $\mathrm{i}+5$ & $\mathrm{i}+5$ & & 0.0 \\
\hline Total caudal fin & $8+8$ & $8+8$ or $8+9$ & & 0.5 \\
\hline
\end{tabular}

pterygiophore large; subsequent ones become progressively shorter. Anal-fin margin truncated. Caudal fin 8+8-9, slightly forked; lobes equal with pointing tips; dorsal lobe procurrent caudal-fin rays 3; ventral lobe procurrent rays 3. Caudal-fin skeleton with parhypural fused with hypurals 1 and 2, separated by deep notch from hypurals 3 to 5 plus uroneural. Epural separated from dorsal hypurals. Vertebrae 22, excluding those incorporated into Weberian complex. Six paired pleural ribs, associated with connective tissues of vertebrae 8-13.

Color in alcohol. Irregular narrow dark brown stripe along trunk, between transverse dark bars, interrupted at certain points in some specimens. Ventral surface of head and belly whitish. Adipose fin with dark blotch at its base. Four irregular brownish bars on trunk; first one close to dorsal-fin origin, second at end of dorsal-fin base, third at adipose-fin origin, and fourth on caudal peduncle. Pelvic and anal fins with few and sparse chromatophores on dorsal side, not forming bands. Pectoral and pelvic fins with branched rays and interradial membranes unpigmented in ventral view. Caudal-fin base with dark vertical bar. Caudal fin with irregular color pattern, but inconspicuous darkened band always present at middle of each lobe. Ground color in ethanol becomes grayish.

Live coloration. Ground color pale yellow. Predorsal area of body mottled with faint small dark blotches (Fig. 3). Longitudinal discontinuous stripe present along lateral line. Unbranched first ray in both dorsal and pectoral fins with alternate series of white and dark spots aligned, forming bands. Subsequent rays with alternate spots, giving maculate pattern to rays. Caudal-fin rays with dark chromatophores forming bands.

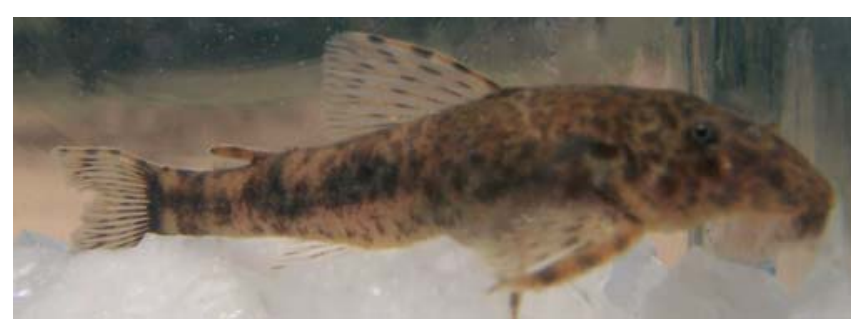

Fig. 3. Parotocinclus arandai, $37.7 \mathrm{~mm}$ SL, specimen photographed in the field.

Distribution. Known from tributaries of the middle and upper rio Jucuruçu and upper rio Buranhém, close to the border of southern Bahia and northeastern Minas Gerais States (Figs. 4 and 5).

Etymology. The specific name arandai honors our ichthyologist colleague Arion Túlio Aranda in recognition of his talent for catching fish and knowledge of their habits.

Ecological notes. Parotocinclus species are small herbivorous catfishes, but little is known about their habits. Benthic habits 


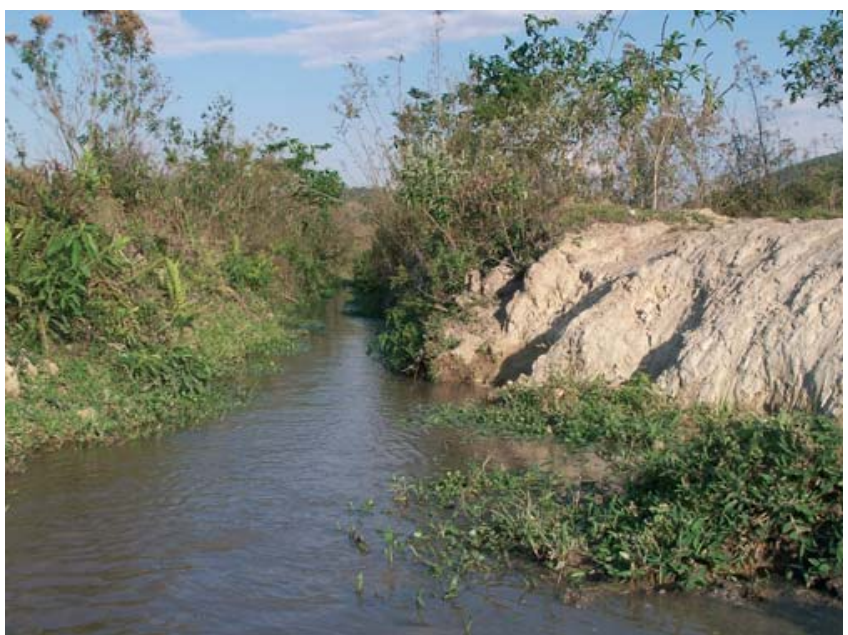

Fig. 4. Type locality of Parotocinclus arandai, córrego Bananeiras, município de Palmópolis, Minas Gerais, Brazil.

or behavior of attachment to submerged marginal vegetation were reported for different species groups by Garavello (1977) and information on diet is available for P. prata in Ribeiro et al. (2002). During this study specimens were collected in clear, shallow waters, approximately $0.3 \mathrm{~m}$ in depth, in moderate flowing sections of the rivers, with a sandy or gravel bottom. Riparian environments were most impacted by agriculture and cattle, and surrounded by mild vegetation and with a few floating meadows.

\section{Discussion}

The genus Parotocinclus has been recognized based on a combination of characters, such as the presence of an adipose fin, head not strongly depressed, eyes not visible in ventral view, pectoral arrector fossae opened (at least partially), region of snout surrounding anterior portion of nostrils plated and slightly depressed, head without crests (Schaefer \& Provenzano, 1993); and on the presence of a caudal fenestrum anterior to notch between hypurals 2 and 3 (Reis \& Schaefer, 1998). These features are all present in $P$. arandai.

The paraphyletic nature of Parotocinclus was initially presented by Gauger \& Buckup (2005) who reanalyzed the phylogenetic relationships of the Hypoptopomatinae including 31 terminal taxa and based on 45 characters of Schaefer (1998) and 11 additional characters. In their study nine Parotocinclus species were analyzed, with the following seven recovered as a monophyletic group: $P$. cearensis, $P$. cesarpintoi, $P$. haroldoi, P. bidentatus, $P$. muriaensis, $P$. doceanus, and $P$. maculicauda. Synapomorphies uniting this restricted monophyletic assemblage of Parotocinclus are a mid-dorsal lateral plate series with more than eight plates, extending beyond the dorsal fin to the caudal peduncle; the fourth infraorbital bone with a relatively small ventral lamina; and an adipose-fin (sometimes replaced by one to three unpaired platelets at typical adipose-fin position). The presence of these characters in $P$. arandai would place it among this monophyletic assemblage recognized as Parotocinclus.

Parotocinclus arandai differs from its congeners in the Atlantic coastal basins of southeastern Brazil, P. bidentatus, $P$. maculicauda, and P. planicauda in having an extensively naked abdomen ( $v s$. covered with plates) and the presence of a small tuft of hypertrophied odontodes on the supraoccipital (vs. absence). Parotocinclus muriaensis shares with $P$. arandai a partially exposed pectoral girdle; the new species is distinguished from both $P$. bidentatus and $P$. muriaensis by the presence of an adipose fin (vs. absence in P. bidentatus and $P$. muriaensis) and by the absence of unicuspid teeth behind the series of bicuspid teeth of the dentary and premaxilla (vs. presence). Parotocinclus arandai is further distinguished from $P$. maculicauda by having four irregular transverse dark bars along the trunk (vs. trunk with a single longitudinal dark stripe along lateral mid-line in $P$. maculicauda) and caudal fin with scattered chromatophores forming a somewhat striped pattern (vs. lower caudal-fin lobe darkened and upper caudal-fin lobe whitish in $P$. maculicauda). Parotocinclus arandai is further distinguished from $P$. planicauda by having 2-4 small plates on lateral series (vs. 5-7 elongated plates on lateral series in $P$. planicauda) and pectoral girdle partially exposed ( $v s$. completely exposed in $P$. planicauda).

The new species is morphologically most similar to species in the Atlantic coastal basins of Eastern Brazil. These basins include all river drainages between the rio Vaza Barris, in

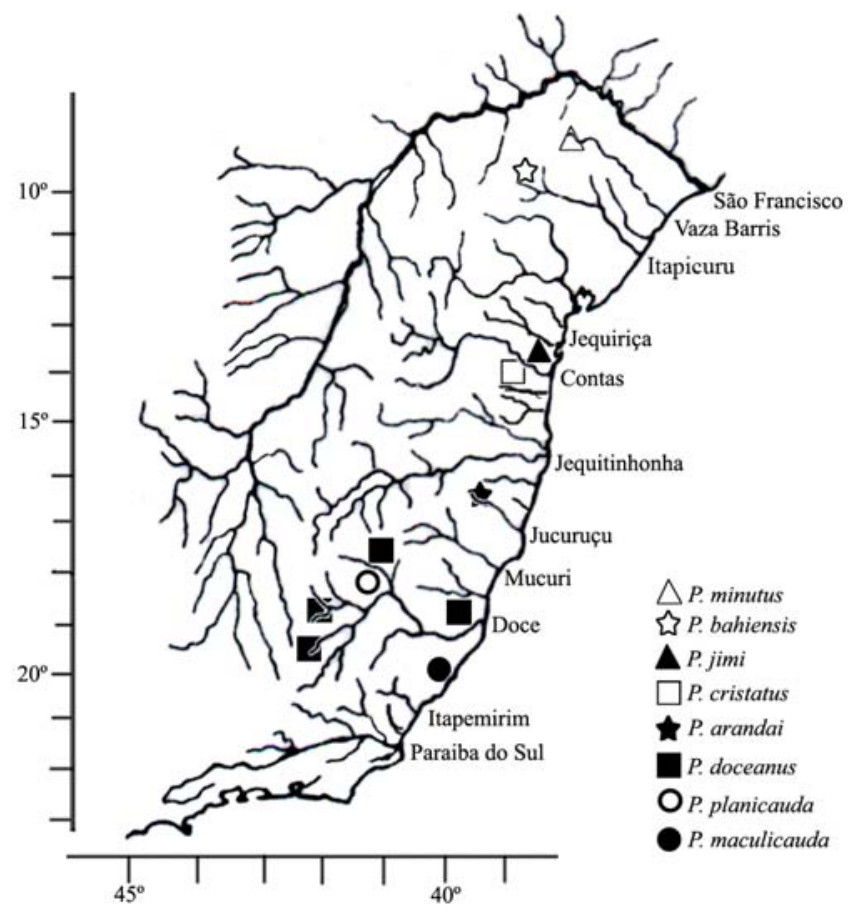

Fig. 5. Drainages of eastern and northeastern Brazil illustrating the distribution of the Parotocinclus species in the area. Symbols may represent more than one locality 
Sergipe State, in the north to the rio São Mateus, Espírito Santo State in the south (Fig. 5). These coastal river drainages harbor five Parotocinclus species: P. bahiensis, $P$. cristatus, $P$. doceanus, $P$. jimi, and $P$. minutus. Parotocinclus arandai differs from all of these species, except $P$. bahiensis, in having extensive naked areas on the abdomen.

Paratocinclus bahiensis was described as Microlepidogaster bahiensis from northern Bahia by Miranda Ribeiro (1918). The type material was caught by E. Garbe in 1908, and since then no additional material became available in collections. The type material disappeared (Britski, 1969). The recognition of this species as a Parotocinclus was made by Garavello (1977), based on the presence of an adipose fin and on the distributional range of the genus. Parotocinclus bahiensis was collected in Vila Nova, Bahia, (Miranda Ribeiro, 1918), a locality now named Senhor do Bonfim. It is situated on the upper portion of rio Itapicuru, a medium sized river drainage on northern Bahia. The original description is little informative and additional specimens of $P$. bahiensis were recently caught at the type locality (A. Zanata, comun. pess.), permitting a detailed comparison with $P$. arandai. Detailed information on $P$. bahiensis morphology was provided by $\mathrm{H}$. A. Britski (pers. comm.), through a redescription of this illknown Parotocinclus species. A direct comparison between individuals of Parotocinclus bahiensis and P. arandai shows that both species have a similar naked abdomen, with a mosaic of small plates and with only a small portion of the pectoral girdle exposed. Although superficially similar, the two species differ regarding the number of 22-23 lateral plates (vs. 24-25 in $P$. bahiensis), and the presence of a small tuft of hypertrophied odontodes on supraoccipital (vs. absence in P. bahiensis). They also differ regarding osteological features, as in the new species the second paired rib is articulated to $8^{\text {th }}$ centrum (vs. $7^{\text {th }}$ in $P$. bahiensis) and have 22 vertebrae (vs. 23 in $P$. bahiensis). There are differences regarding proportional measurements, as a small eye $14.8-19.3 \%$ HL in P. arandai (vs. large eye 23.4-26.7\% HL in P. bahiensis). The remaining Parotocinclus species from the Atlantic coastal basins of eastern Brazil are morphologically very different from $P$. arandai, as all of them do possess an abdomen covered with plates and a completely exposed pectoral girdle.

We observed a remarkable pattern of endemism in the fish fauna from the rio São Mateus to the rivers in the extreme south of Bahia, south of the rio Jequitinhonha. Fish species restricted to coastal river drainages between northern Espírito Santo and extreme southern Bahia include Oligosarcus acutirostris, Rachoviscus graciliceps, Mimagoniates sylvicola, Aspidoras virgulatus, Pogonopoma wertheimeri, Pseudauchenipterus affinis, and also Phalloceros ocellatus. Parotocinclus arandai appears to be an addition to this list.

Comparative Material. Parotocinclus aripuanensis: MZUSP 36899, 1, paratype (20.9 mm SL), MZUSP 36903, 1, paratype (18.4 mm SL); Parocinclus amazonensis: MZUSP 10145, 1 holotype (14.9 mm SL); Parotocinclus bahiensis: MBML 2124, 8
(14.5-31.2 mm SL); MBML 2147, 2 c\&s (23.7-29.5 mm SL). Parotocinclus bidentatus: MNRJ 17467, 1, paratype (30.7 mm SL); MNRJ 27962, 1, holotype (37.9 mm SL); MNRJ 28255, 1, paratype (34.4 mm SL). Parotocinclus britskii: INHS 31733, 12, 2 c\&s (20.40-24.45 mm SL); ANSP 179139, 1 (I); MCP 34709, 10 (17.76-21.12 mm SL). Parotocinclus cearensis: MNRJ 10155, 1, paratype (23.7 mm SL); MNRJ 10156, 1, paratype (24.4 mm SL); MNRJ 10157, 1, paratype (22.8 mm SL); MNRJ 10158, 1, paratype (23.7 mm SL); MNRJ 10159, 1, paratype (25.6 mm SL); MNRJ 10160, 1, paratype (25.8 mm SL). Parotocinclus cesarpintoi: MCP 30562, 2 c\&s (20.66-30.81 mm SL), MCP 30562, 11 (10.04-31.11 mm SL); MNRJ 1153, 4, 2, syntypes (36.64-39.66 mm SL); MNRJ 1154, 8, 2c\&s, syntypes; MNRJ 10142, 1, paratype (32.5 mm SL); MNRJ 10150, 1, paratype (41.4 mm SL). Parotocinclus collinsae: AMNH 55433, 1, holotype (24.8 mm SL), AMNH 55434, 2 paratypes (18.39-25.15 mm SL). Parotocinclus cristatus: MCP 18116, 33 (20.08-38.64 mm SL), MCP 41337, 2 (31.21-33.75 mm SL), MCP 36813, 12, 2 c\&s ( 28.03-30.76 mm SL), MCP 18116, 2 c\&s (30.93-33.42 mm SL); MNRJ 10132, 1, holotype (36.60 mm SL), MNRJ 10127,1, paratype (27.6 mm SL), MNRJ 10128, 1, paratype (27.2 mm SL), MNRJ 10129, 1, paratype (27.6 mm SL), MNRJ 10130, 1, paratype (25.5 mm SL), MNRJ 10131, 1, paratype (29,1 mm SL), MNRJ 22933, 19, 2 c\&s (29.3- 33.1 mm SL). Parotocinclus doceanus: MBML 493, 12 (33,6-39,1 mm SL); MBML 1058, 8 (29.8-43.8 mm SL); MCP 18084, 18, 4 c\&s (16.1-35.53 mm SL); MNRJ 18041, 3 (34.3-36.7 mm SL), MNRJ 18046, 2 (35.8-38.3 mm SL), MNRJ 21023, 5 (31.0-35.1 mm SL), MNRJ 21032, 1 (28.5 mm SL). Parotocinclus eppleyi: MCP 33313, 10, 2c\&s, paratypes (20.47-28.93 mm SL); ANSP 162164 (I). Parotocinclus haroldoi: MNRJ 11738, 1, paratype (31.0 mm SL), MNRJ 11383:18, 5, 3 c\&s, paratypes (31.04 - 34.85 mm SL). Parotocinclus jimi: MCP 36891, 3 (24.14-35.67 mm SL), MCP 34397, 21 (23.05-36.81 mm SL); MZUSP 12154:193, 17, paratypes (20.11-34.53 mm SL), 2 c\&s (26.67-28.23 mm SL), MCP 33329, 1 (36.28 mm SL); MNRJ 21654, 1 (31.5 mm SL). Parotocinclus jumbo: MCP 30563, 42 (17.24-41.43 mm SL), MCP 31107, 3 c\&s (14.4-34.68 mm SL); MNRJ 21924, 5, paratypes (38.2-40.0 mm SL). Parotocinclus maculicauda: MBML 439, 21 (37.8-45.2 mm SL); MBML 491, 1 (41,3 mm SL); MBML 673, 2 (38,6-40,0 mm SL); MBML 697, 6 (39.5-52.3 mm SL); MBML 730, 4 (46.7-50.3 mm SL); MBML 798, 1 (47.6 mm SL); MBML 1097, 6 (40.7-42.5 mm SL); MBML 1216, 3 (37.2-40.6 mm SL); MCP 29086, 2 c\&s (42.42-42.60 mm SL), MCP 20075, 6 (42.8748.37 mm SL); MNRJ 5118, 1 (41.1 mm SL), MNRJ 10094, 1 (41.7 mm SL), MNRJ 10095, 1 (40.5 mm SL), MNRJ 10096, 1 (41.1 mm SL), MNRJ 10097, 1 (46.6 mm SL), MNRJ 10120, 1 (38.1 mm SL), MNRJ 10121, 1 (35.3 mm SL), MNRJ 19385, 1 (41.3 mm SL), MNRJ 24346, 6 (34.2-42.2 mm SL), MNRJ 24368, 1 (49.1 mm SL); NMW 45381:2, 1, paralectotype (34.67 mm SL). Parotocinclus minutus: MCP 40034, 8 (25.19-28.8 mm SL), MCP 40034, 2 (27.95-28.68 mm SL); MNRJ 13773, 41 (27.4-32.8 mm SL). Parotocinclus muriaensis: MNRJ 14753, 4, paratypes (25.830.5 mm SL). Parotocinclus longirostris: MZUSP 36892, 1, paratype (26.5 mm SL); MZUSP 85796, 21, 3 c\&s (14. 5-26.41 mm SL). Parotocinclus planicauda: MBML 1276, 1 (26,9 mm SL); MCP 31317, 2 c\&s (32.83-34.55 mm SL), MCP 27321, 1 c\&s (36.84 mm SL), MZUSP 69348, 1 (42.7 mm SL), MZUSP 69364, 1 (38.6 mm SL), MZUSP 69360, 1 (38.6 mm SL), MZUSP 75051, 1 (34.8 mm SL), MZUSP 75053, 1 (35.5 mm SL), MZUSP 75057, 1 (33.0 mm SL), MZUSP 75097, 1 (36.7 mm SL). Parotocinclus polyochrus: AMNH 74482, 1 holotype (27.35 mm 
SL), AMNH 77520, 1, paratype (26.03 mm SL). Parotocinclus prata: MCP 27381, 4, 2 c\&s, paratypes (28.32-49.5 mm SL). Parotocinclus spilosoma: ANSP 69410, 1, holotype (40.10 mm SL); ANSP 69417, 24, paratypes (24.2-33.2 mm SL); AUM 20581, 28 (26.84-43.56 mm SL); MCP 39165, 4 c\&s (25.61-36.19 mm SL). Parotocinclus spilurus: ANSP 69403, 1, holotype (29.49 mm SL), ANSP 69404, 4, 1 c\&s, paratypes (25.58-28.20 mm SL). Parotocinclus sp. 3 (rio Jequitinhonha): MBML 1494, 12 (33.835.4 mm SL); MBML 2148, 2 c\&s (33.1-37.0 mm SL); MCP 43936, 3 (30.4-33.5 mm SL); MCP 43937, 1 c\&s (29.3 mm SL); MNRJ 22516, 2 (36.3-38.3 mm SL).

\section{Acknowledgements}

We wish to thank the Setor de Ictiologia of the Museu Nacional, particularly Paulo A. Buckup, Marcelo R. Britto and Gustavo W. Nunan. We are grateful to Mikael Martinelli, Fernando Flores and Rogério L. Teixeira for their help at the Museu de Biologia Mello Leitão. We acknowledge Angela Zanata for information on Itapicuru river expedition and Alexandre Clistenes A. Santos for the exchange of specimens of Parotocinclus bahiensis captured on the type locality. To Arion T. Aranda, Carine C. Chamon and Rogério L. Teixeira for their help during fieldwork. Thanks to Margarete Lucena (MCP) for support in the museum collection. Thanks also to Fernanda Mayer for the assistance in the Laboratory of Ichthyology of the Pontifícia Universidade Católica do Rio Grande do Sul. We are indebted to Mark H. Sabaj and Kyle Luckenbill for providing images of specimens at ANSP. We are grateful to Heraldo A. Britski for valuable suggestions and comments regarding the identity of Parotocinclus bahiensis. The paper benefited from the comments and suggestions of Carine C. Chamon and Scott A. Schaefer. Funding for the fieldwork was provided by the All Catfish Species Inventory, supported by the National Science Foundation, NSF DEB-0315963. We are also indebted to the Instituto Brasileiro do Meio Ambiente e dos Recursos Naturais Renováveis (IBAMA) for facilitating the collection permit for the study area. The senior author received financial support through a Post-Doctoral Grant by the CNPq- Conselho Nacional de Desenvolvimento Científico e Tecnológico (process \#154358/2006-1).

\section{Literature Cited}

Boeseman, M. 1968. The genus Hypostomus Lacépède, 1803, and its Surinam representatives (Siluriformes, Loricariidae). Zoologische Verhandelingen, 99: 1-89.

Britski, H. A. 1969. Lista dos tipos de peixes das coleções do Departamento de Zoologia da Secretaria da Agricultura, São Paulo. Papéis Avulsos de Zoologia (São Paulo), 22: 197-215.

Britski, H. A. \& J. C. Garavello. 1984. Two new southeastern Brazilian genera of Hypoptopomatinae and a redescription of Pseudotocinclus Nichols, 1919 (Ostariophysi, Loricariidae). Papéis Avulsos de Zoologia (São Paulo), 35: 225-241.

Carvalho, T., P. Lehmann \& R. E. Reis. 2008. Gymnotocinclus anosteos, a new uniquely-plated genus and species of loricariid catfish (Teleostei: Siluriformes) from the upper rio Tocantins basin, central Brazil. Neotropical Ichthyology, 6(3): 329-338.

Garavello, J. C. 1977. Systematics and geographical distribution of the genus Parotocinclus Eigenmann \& Eigenmann, 1889 (Ostariophysi, Loricariidae). Arquivos de Zoologia, 28: 1-37.

Gauger, M. F. W. \& P. A. Buckup. 2005. Two new species of Hypoptopomatinae from the rio Paraíba do Sul basin, with comments on the monophyly of Parotocinclus and the Otothyrini (Siluriformes: Loricariidae). Neotropical Ichthyology, 3(4): 509-518.

Lehmann, P. 2006. Anatomia e relações filogenéticas da família Loricariidae (Ostariophysi: Siluriformes) com ênfase na subfamília Hypoptopomatinae. Unpublished Ph.D. Dissertation, Pontifícia Universidade Católica do Rio Grande do Sul, Porto Alegre, 420p.

Leviton, A. E., R. H. Gibbs, E. Heal \& C. E. Dawson. 1985. Standards in Herpetology and Ichthyology. Part I. Standard Symbolic Codes For Institutional Resource Collections In Herpetology And Ichthyology. Copeia, 1985(3): 802-832.

Miranda Ribeiro, A. 1918. Três gêneros e dezessete novas espécies de peixes brasileiros. Revista do Museu Paulista, 10: 629-646.

Reis, R. E. \& S. A. Schaefer. 1998. New Cascudinhos from Southern Brazil: Systematics, Endemism, and Relationships (Siluriformes, Loricariidae, Hypoptopomatinae). American Museum Novitates, 3254: 1-25.

Ribeiro, A. C., A. L. A. Melo, \& E. H. L. Pereira. 2002. A new species of Parotocinclus (Siluriformes: Loricariidae) from the rio São Francisco basin, southeastern Brazil. Ichthyological Exploration of Freshwaters, 13: 217-224.

Schaefer, S. A. 1991. Phylogenetic analysis of the loricariid subfamily Hypoptopomatinae (Pisces: Siluroidei: Loricariidae), with comments on generic diagnoses and geographic distribution. Zoological Journal of the Linnean Society, 102: 1-41.

Schaefer, S. A. 1997. The neotropical cascudinhos: Systematics and biogeography of the Otocinclus catfishes (Siluriformes: Loricariidae). Proceedings of the Academy of Natural Sciences of Philadelphia, 148: 1-120.

Schaefer, S. A. 1998. Conflict and resolution: Impact of new taxa on phylogenetic studies of the neotropical cascudinhos (Siluroidei: Loricariidae). Pp. 375-400. In: Malabarba, L. R., R. E. Reis, R. P. Vari, C. A. S. Lucena \& Z. M. S. Lucena. (Eds.). Phylogeny and classification of neotropical fishes. Porto Alegre, Edipucrs, 603p.

Schaefer, S. A. \& F. Provenzano. 1993. The Guyana Shield Parotocinclus: systematics, biogeography, and description of a new Venezuelan species (Siluroidei: Loricariidae). Ichthyological Exploration of Freshwaters, 4: 39-56.

Taylor, W. R. \& G. C. Van Dyke. 1985. Revised procedures for staining and clearing small fishes and other vertebrates for bone and cartilage study. Cybium, 9: 107-119.

Accepted May 2009 Published June 17, 2009 